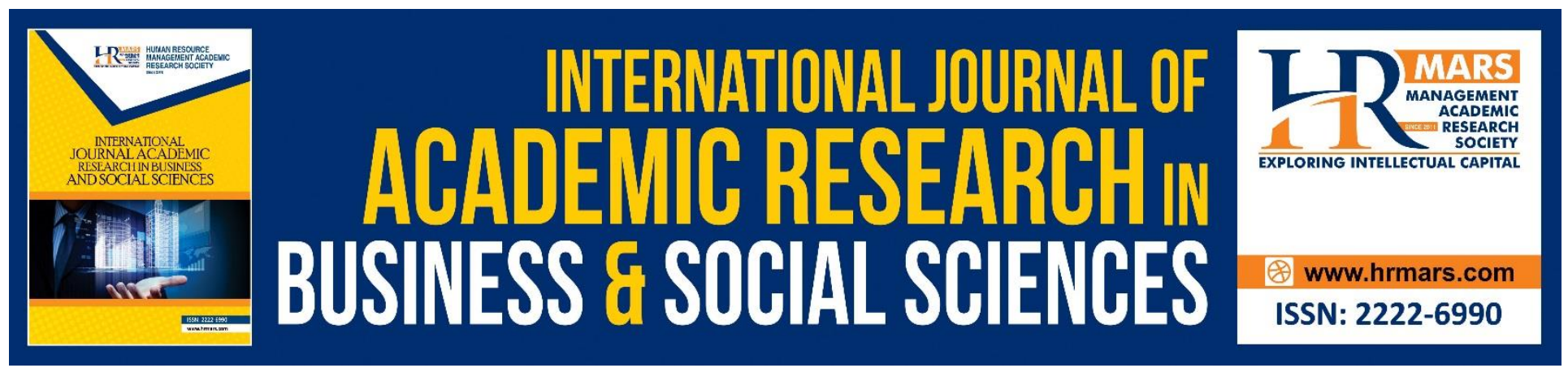

\title{
Factors Influencing Product Innovation Success: The Mediating Effects of R\&D-Marketing Integration
}

\section{Haslinda Mohamed, Saidatul Akmar Ismail, Nor Rashimahwati Tarmuchi}

To Link this Article: http://dx.doi.org/10.6007/IJARBSS/v8-i9/4602

DOI: $10.6007 /$ IJARBSS/v8-i9/4602

Received: 19 August 2018, Revised: 23 September 2018, Accepted: 29 September 2018

Published Online: 15 October 2018

In-Text Citation: (Mohamed, Ismail, \& Tarmuchi, 2018)

To Cite this Article: Mohamed, H., Ismail, S. A., \& Tarmuchi, N. R. (2018). Factors Influencing Product Innovation Success: The Mediating Effects of R\&D-Marketing Integration. International Journal of Academic Research in Business and Social Sciences, 8(9), 414-438.

Copyright: (C) 2018 The Author(s)

Published by Human Resource Management Academic Research Society (www.hrmars.com)

This article is published under the Creative Commons Attribution (CC BY 4.0) license. Anyone may reproduce, distribute, translate and create derivative works of this article (for both commercial and non-commercial purposes), subject to full attribution to the original publication and authors. The full terms of this license may be seen at: http://creativecommons.org/licences/by/4.0/legalcode

Vol. 8, No. 9, September 2018, Pg. 414 - 438

Full Terms \& Conditions of access and use can be found at http://hrmars.com/index.php/pages/detail/publication-ethics 


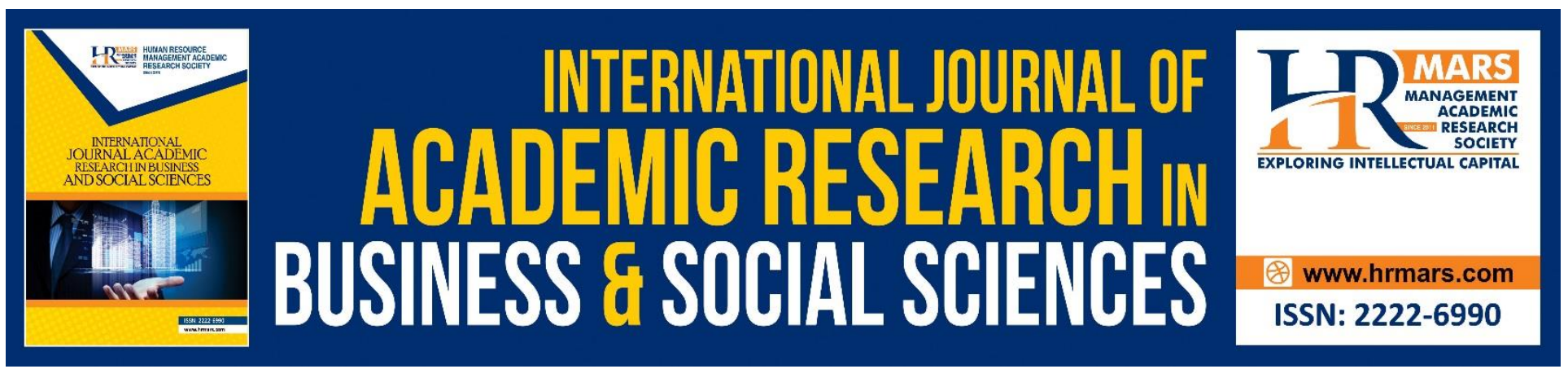

\title{
Factors Influencing Product Innovation Success: The Mediating Effects of R\&D-Marketing Integration
}

\author{
Haslinda Mohamed ${ }^{1}$, Saidatul Akmar Ismail², Nor Rashimahwati \\ Tarmuchi ${ }^{3}$ \\ ${ }^{1}$ Jalinan IImu Sdn Bhd, Shah Alam, Selangor, Malaysia. \\ 2,3 Universiti Teknologi MARA (UiTM), UiTM Selangor, Shah Alam, Selangor, Malaysia.
}

\begin{abstract}
Higher education institutions are hubs of knowledge and expertise, and these institutions can connect their experts from various fields, their students and researchers with professionals from the public or private sectors, in exploring research ideas, developing and testing those ideas, and eventually commercializing them. With the proper R\&D setting at these higher education institutions, successful innovations can likely be the outcome of those activities. There is no unique approach in which higher education institutions can act entrepreneurially. One important aspect is their ability to generate income through commercialization of product innovations. As public funding becomes increasingly constrained, many higher education institutions are encouraged to raise their own revenue. In this light, the paper will discuss factors that influence product innovation performance in organizations based on several empirical studies. This paper introduces crowd capability, organizational factors, and environmental uncertainty to study their effects on $\mathrm{t} \mathrm{h}$ e product innovation success at higher education institutions directly or mediated by R\&Dmarketing integration. The aim of this paper is to propose a conceptual framework that will incorporate crowd capital theory (Prpić \& Shukla, 2013) in the study of R\&D-marketing integration in the innovation process, expanding the works of Gupta, Raj, and Wilemon (1986).
\end{abstract}

Keywords: Innovation, R\&D-marketing Integration, Organizational Factors, Environmental Uncertainty, Crowd Capability

\section{Introduction}

Knowledge is an important asset that can drive the economy and one of the challenges felt by growing businesses is to find skilled employees with a means to be innovative. According to Hisrich and Peters (1992), being innovative is one of the personal entrepreneurial skills, in addition to being disciplined and persistent, willing to take the risk, change-oriented, a visionary leader, and able to manage change. In higher education institutions, experts from various fields, students, and researchers can connect with professionals from the public or private sectors, in exploring research ideas, developing those ideas, and commercializing the newborn products. Moreover, there 
INTERNATIONAL JOURNAL OF ACADEMIC RESEARCH IN BUSINESS AND SOCIAL SCIENCES Vol. 8, No. 9, Sept. 2018, E-ISSN: 2222-6990 @ 2018 HRMARS

are entrepreneurial talents waiting to be discovered within these groups. With the proper R\&D setting, successful innovations can likely be the outcome of those activities.

To promote a continuous interaction and flexible exchange of information, institutions require good leadership, governance, and involvement from external stakeholders. A broad literature can be found in higher education institutions being entrepreneurial-"enterprising universities" (Williams, 1992; Abd Rahman, Farley, \& Ng, 2013), "corporatization of universities" (Abd Rahman, Farley, \& Ng, 2013), "innovative and entrepreneurial universities" (Clark, 1998, 2001, 2004), "selfreliant and successful universities" (Shattock, 2003) and "adaptive universities" (Sporn, 1999). Gibb (2013) gives a more complete definition of an entrepreneurial higher education institution, as below:

Entrepreneurial higher education institutions are designed to empower staff and students to demonstrate enterprise, innovation and creativity in research, teaching and the pursuit and use of knowledge across boundaries. They contribute effectively to the enhancement of learning in a societal environment characterized by high levels of uncertainty and complexity and they are dedicated to creating public value via a process of open engagement, mutual learning, discovery, and exchange with all stakeholders in society local, national and international (Gibb, 2013).

Higher education institutions can create the conditions for businesses to deliver growth through partnerships and R\&D. This collaboration is a win-win as getting entrepreneurs into the institutions may bring the opportunity for them to spark a start-up culture into the higher education system (Etzkowitz, 2008). There is no one-way approach, but there can be a variety of ways in which higher education institutions can act entrepreneurially, for example, in how they manage resources and build organizational capacity, involve external stakeholders into their leadership and governance, create and encourage collaborations between teaching, research, and their community engagement, promote entrepreneurship through education, and business start-up support and knowledge exchange, to enhance the innovation performance (Barber et al., 2013)

In the Malaysian context, Raja Suzana (2011) mentions that Malaysia has not been very effective at converting research outputs into business innovation, competitive advantage, and social benefits. Nurturing an enterprising culture into the system and policy of higher education institutions appears to be one of the driving factors which can help to translate the knowledge output of the university into business innovation. To incorporate entrepreneurial activity in teaching, learning, and research, the university has opened up an entrepreneurial development center, which stresses the importance of building strong relationships between higher education institutions and employers (Raja Suzana, 2011). Abd Rahman, Farley, and Ng (2013), in their study on funding reforms in Malaysian public universities, state that the Ministry of Education Malaysia focuses on strategic studies and research at universities across the country to ensure the better impact of enriching the knowledge and the national economy. The Malaysian government has encouraged public universities to make collaboration between research universities and corporate entities in commercialization universities research.

The concept of a corporate or an entrepreneurial university is in line with financial issues faced by the higher education institutions (Clark, 2003). It is noted that many universities face difficulties 
INTERNATIONAL JOURNAL OF ACADEMIC RESEARCH IN BUSINESS AND SOCIAL SCIENCES Vol. 8, No. 9, Sept. 2018, E-ISSN: 2222-6990 @ 2018 HRMARS

in creating a sole university- generated income with its core activities geared towards enterprise development (Burg, Romme, Gilsing, \& Reymen, 2008; Handscombe, 2003; Kothari \& Handscombe, 2007), such as enterprise modules and courses, regional and national business plan competitions, and venture fests (Clark, 2003). Both the external and internal factors that appear to contribute to the growth of entrepreneurial universities need to be explored. Hence, in taking up this challenge, this paper will first identify several determinants of product innovation success based on several empirical studies to examine the factors that influence product innovation performance.

There are several kinds of literature which study the influence of organizational factors and environmental uncertainty on product innovation performance (Valencia, Valle, \& Jimenez, 2010; Tatikonda \& Montoya-Weiss, 2001; Lily Julienti \& Hartini, 2010). However, these studies are demographically lacking in the education sector and are more focus on organizational innovations and process-based innovations (Obenchain, 2002; Ganter \& Hecker, 2013, 2014; Mei-Chih \& Mathews, 2009). In addition, organizational factors and environmental uncertainty are most commonly examined together with cross-functional collaboration and R\&D-marketing integration (Fain \& Wagner, 2014; Lu \& Chang, 2002; Song \& Thieme, 2006). However, there is a gap in the literature about the effects of $R \& D$-marketing integration on innovation performance in the education sector.

Higher education institutions have the technical knowledge and skills to innovate, but may lack the marketing and business knowledge to commercialize products, which is the ultimate goal of entrepreneurial activities (Yahya \& Abdullah, 2004; Raja Suzana, 2011; Williams, 2009). Hence, to incorporate R\&D-marketing integration in this study is considered appropriate.

The influence of crowd on innovation performance can also be seen in several kinds of literature (Belleflamme \& Lambert, 2014; Ordanini et al., 2011; Surowiecki, 2004). Because this branch of study is relatively new, there is a lack of empirical research on this topic and their focus is on crowd behavior and motivations of the crowd to participate (Belleflamme, Lambert, \& Schwienbacher, 2014; Kuppuswamy \& Bayus, 2014; Lambert \& Schwienbacher, 2010). There is also a gap in the study of the crowd in the education sector and their attention is on the educational technology innovation and motivations of the crowd to participate (Antonenko, Lee, \& Kleinheksel, 2014). In addition, due to the nature of the business of higher education institutions, they appear to have a direct link with the public, their alumni, the industries, and the government (Gibb, 2013; Shattock, 2010; Williams, 2009; Smart \& St. John, 1996). This gives the institutions an advantage when engaging "the crowd" in their projects and research works for funds or professional advice. A participant from the crowd, as stated in several kinds of literature (Prpić \& Shukla, 2013; Belleflamme, Lambert, \& Schwienbacher, 2014), can be an individual or an organization. In light of filling the literature gaps, this paper introduces crowd capability, organizational factors, and environmental uncertainty to investigate their effects on the product innovation success at higher education institutions directly or mediated by R\&D- marketing integration.

The aim of this paper is to propose a conceptual framework that will incorporate crowd capital theory (Prpić \& Shukla, 2013) in the study of R\&D-marketing integration in the innovation process, expanding the works of Gupta, Raj, and Wilemon (1986). 
INTERNATIONAL JOURNAL OF ACADEMIC RESEARCH IN BUSINESS AND SOCIAL SCIENCES Vol. 8, No. 9, Sept. 2018, E-ISSN: 2222-6990 @ 2018 HRMARS

\section{Literature Review}

In this section, each variable and its proposed relationships with the outcome of this research will be discussed. The author uses product innovation success, as a general term for the outcome, to represent the performance of higher education institutions in their entrepreneurial activities that result in the number of patents granted, products licensed for commercialization, and IPR/copyrights (Raja Suzana, 2011).

\section{Product innovation success}

Several definitions of product innovation performance have been used in literature, but, none agrees on a common basis for measuring a company's innovativeness (Avermaete et al., 2003). Lee, Wu, and Pao (2014) and Katila and Ahuja (2002) measure firms explorativeness by adopting a patent citation-based measure. Christofi, Vrontis, and Leonidou (2014) define product innovation as a continuous and cross-functional process involving and encompassing a growing number of various competencies inside and outside the organizational boundaries. According to Cormican \& O'Sullivan (2004), it is the process of transfiguring business opportunities into tangible products and services. Mei-Chih and Mathews (2009) measure innovation performance by patent grants, licensing revenues, industry, and academic cooperation, and incubating firms.

Several other literatures use product-based goals (Zairi, 1995; Nee, Kang, \& Opper, 2010) and process-based goals (Zairi, 1995; Li \& Chen, 2012; Nee, Kang, \& Opper, 2010), as well as quality control (Nee, Kang, \& Opper, 2010) to measure firm innovativeness. Li and Chen (2012) elaborate that new product development is a complicated process that consists of many phases and activities, including idea generation, concept development, prototype design, business analysis, test marketing, and product launch (Cooper, 2000; Laforet, 2008). There are various indicators that measure product innovation, however, a number of patents, new product announcements, and degree of innovation have received the most attention (Niammuad, Napompech, \& Suwanmaneepong, 2014; Laforet, 2008; Lee, Wu, \& Pao, 2014; Löfsten, 2014; Otero-Neira, Arias, \& Lindman, 2013; Jiménez-Zarco, Torrent-Sellens, Martinez-Ruiz, 2010; Vega-Vázquez, Cossio-Silva, \& Martin-Ruiz, 2012). Nevertheless, according to Niammuad, Napompech, and Suwanmaneepong (2014), in business services such as the software industry, a number of patents and new product announcements are unsatisfactory indicators for measuring firms' innovation (Wetering \& Koster, 2007).

The failure or the success of product innovation is identified through product innovation performance (PIP) indicators (Lily Julienti \& Hartini, 2010). PIP has been defined as the economic, financial and non-financial outcomes of the firm's product innovation efforts (Cooper \& Kleinschmidt, 1987; Gemunden \& Heydebreck, 1992; Hise \& O'Neal, 1990; Hollenstein, 1996). Measurements of product performance for RBV studies, in particular, are also classified into financial (accountingbased measurement such as cash in hand/at bank, profitability, sales growth) and non- financial (market share, new product introduction, product quality, marketing effectiveness or manufacturing value- added) (Kapelko, 2006). According to several kinds of literature, profitability and sales growth are the most common measurements of performance (Doyle, 1994; Kasim, Minai, \& Chun, 1989; Löfsten, 2014). 
INTERNATIONAL JOURNAL OF ACADEMIC RESEARCH IN BUSINESS AND SOCIAL SCIENCES Vol. 8, No. 9, Sept. 2018, E-ISSN: 2222-6990 @ 2018 HRMARS

Laforet (2008) reports benchmarking literature suggests a number of indicators for firms innovativeness. Laforet (2008) also highlights that the Department of Trade and Industry (DTI) together with the Confederation of British Industry (CBI) in the UK have introduced ten indicators of firm innovativeness. For the purpose of this study, the author will use one of the five indicators-commercial success rate, technological success rate, effect on company activities, financial success rate and market share (Griffin \& Hauser, 1996; Huang, Soutar, \& Brown, 2004) and measure product innovation performance by assessing the commercial success rate. In the same light, this study will measure the direct impact of innovation on entrepreneurial activities through its achievement of a number of patents granted, products licensed for commercialization, and IPR/copyrights (Raja Suzana, 2011).

\section{Organizational factors and innovation success}

Organizational culture can be defined as the values, beliefs and hidden assumptions that organizational members have in common (Cameron \& Quinn, 1999; Deshpande, Farley, \& Webster, 1993; Valencia, Valle, \& Jimenez, 2010). Various research works have been conclusive as to the key role of culture in innovation (Valencia, Valle, \& Jimenez, 2010; Tatikonda \& MontoyaWeiss, 2001; Lily Julienti \& Hartini, 2010).

The organizational culture and the organizational effectiveness in higher education institutions have been examined by Obenchain (2002). In her study, she identifies culture profile of an organization to be categorized as-clan, hierarchy, adhocracy, and market. Service organizations (Cameron \& Quinn, 1999) including hospitals (Zammuto, Gifford, \& Goodman, 2001), and financial services (Cameron \& Quinn, 1999) routinely reflect the clan culture, which embraces group values of loyalty, teamwork, and interpersonal cohesion. For higher education institutions, Obenchain and Johnson (2004) find organizations desiring innovating could either embrace the adhocracy culture or seek to balance the organizational operating values among the various culture types of the clan, adhocracy, market, and hierarchy.

Studies on culture type within the business domain (Deshpande, Farley, \& Webster, 1993) and education domain (Cameron, 1985; Zammuto \& Krackower, 1991; Smart \& St. John, 1996; Obenchain \& Johnson, 2004) have identified dominant culture types among sample populations. Fain and Wagner (2014), on the other hand, in their study of the effects of cultural dimension on new product development success, adopt the most commonly used cultural framework in psychology, sociology, marketing and management studies, the Hofstede's framework. It consists of five cultural dimensions - individualism-collectivism, uncertainty avoidance, power distance, masculinity-femininity and long-term orientation.

Organizational characteristics include a wide range of variables such as: age, organizational type, size, resources, structural variables (such as formalization, centralization, complexity), internal communication characteristics, and organizational climate and culture (Calisir, 2013; Fain \& Wagner, 2014; Cheng, Chang, \& Li, 2013; Christofi, Vrontis, \& Leonidou, 2014). Similarly, Obenchain (2002), in her study of organizational culture and organizational innovation, uses organizational structure dimension and includes variables such as complexity, centralization, formalization, vertical differentiation, and interconnectedness. Other dimensions used in the organizational related factors are consensual, mechanistic, and entrepreneurial (Misyer, Omar, \& 
INTERNATIONAL JOURNAL OF ACADEMIC RESEARCH IN BUSINESS AND SOCIAL SCIENCES Vol. 8, No. 9, Sept. 2018, E-ISSN: 2222-6990 @ 2018 HRMARS

Normaziah, 2012). While factors such as organizational size, resources, centralization, and formalization remain as popular variables of study, yet the results have been mixed (Rogers, 1995; Shin, 1996; Hurley \& Hult, 1998). Blau and Scott (1962), Miller (1992), Gupta, Raj, and Wilemon (1986), and Fain and Wagner (2014) agree that these variables cannot be ignored in research designs. In view of R\&D-marketing integration, literature suggests several important mechanisms (Lu \& Chang, 2002; Maltz \& Kohli, 2000; Song \& Thieme, 2006; Garett, Buisson, \& Yap, 2006) and according to Fain and Wagner (2014), their study of existing literature in the field shows that formalization, centralization, and organizational climate are the most widely used integrative mechanisms.

Despite the importance given to culture as a driver for innovation, empirical research remains limited. Some studies on the link between culture and innovation, examine only at some elements of culture (Calisir, 2013; Fain \& Wagner, 2014; Cheng, Chang, \& Li, 2013; Christofi, Vrontis, \& Leonidou, 2014) and they do not generally use the same culture typology (Obenchain \& Johnson, 2004; Obenchain, 2002). Furthermore, the results could not be generalized to the Malaysian context. Due to this, there comes the need to research culture and innovation empirically (Laforet, 2008; Lee, Wu, \& Pao, 2014; Misyer, Omar, \& Normaziah, 2012; Silva, Gomez, Lages, \& Pereira, 2014).

In summary, a large number of variables have been proposed as determinants of innovation and these can be grouped as individual factors, organizational factors, and environmental factors. This paper will firstly discuss organizational factors, particularly formalization, centralization, and organizational climate, since the literature has identified these as having the most effect on innovation (Damanpour, 1991) and are included in the study of R\&D-marketing integration (Fain \& Wagner, 2014; Gupta, Raj, \& Wilemon, 1986).

\section{Formalization}

Regarding the organizational characteristic of formalization, Rogers (1995) defines it as the degree to which an organization emphasizes following rules and procedures in the role performance of its members (Lu \& Chang, 2002; Song \& Thieme, 2006). In general, formalization is believed to act as an inhibitor to the consideration of innovations (Zaltman, Duncan, \& Holbek, 1973; Rogers, 1983, 1995; Fain \& Wagner, 2014), and yet is suggested to encourage the implementation of them (Neal \& Radnor, 1971). As highlighted by Gupta, Raj, and Wilemon (1986), formalization may cause noninvolvement among professionals.

In the study of organizational innovation, there is a negative relationship between formalization and organizational innovation according to the organization theory. Flexibility and low emphasis on work rules facilitate innovation (Burns \& Stalker, 1961; Thompson, 1965; Aiken \& Hage, 1971). Low formalization permits openness, which encourages new ideas and behaviors (Pierce \& Delbecq, 1977). In contrast, Damanpour's (1991) finds that the association of formalization with innovation is barely significant.

However, in a recent study conducted by Fain and Wagner (2014) formalization is perceived as important for new product development at the UK company. The greater the levels of formalization, the better new product development success will be. For the Slovenian company, formalization is perceived as a disabler of new product development success. The negative significant direct effect 
INTERNATIONAL JOURNAL OF ACADEMIC RESEARCH IN BUSINESS AND SOCIAL SCIENCES

Vol. 8, No. 9, Sept. 2018, E-ISSN: 2222-6990 @ 2018 HRMARS

indicates that the Slovenian company perceives new product development success is influenced by formalization. Formalization appears to be both a facilitator, as well as a barrier to product development success. Hence, in this study, the author follows the reasoning proposed by Obenchain and Johnson (2004). They study both adhocracy and hierarchy cultures in institutions of higher education. They find evidence that it is the adhocracy cultures which most favor innovation while hierarchical cultures hinder it. As stated by Cameron and Quinn (1999), hierarchy culture is characterized by stability and internal orientation, which favors decision making by authority, high formalization, an emphasis on internal processes, and therefore, would be negatively related to innovation. Given the above, the author hypothesizes:

$\mathrm{H} 1$ : Formalization has a negative effect on product innovation success.

\section{Centralization}

Regarding the organizational characteristic of centralization, Rogers (1995) defines it as the degree to which power and control in a system are concentrated in the hands of relatively few individuals (Lu \& Chang, 2002; Song \& Thieme, 2006). Meanwhile, Gupta, Raj, and Wilemon (1986) conceptualize centralization in terms of a hierarchy of authority and degree of participation in decision making. Rogers (1995) reports that centralization may encourage the implementation of innovations. In contrast, centralization is believed to also act as an inhibitor to innovation as it restricts channels of communication and reduces available information (Burns \& Stalker, 1961; Hage \& Aiken, 1967; Rogers, 1983, 1995). Fain and Wagner's (2014) analysis of two engineering firms from the UK and Slovenia, it is reported that the test of the direct effect of centralization on new product development success shows no significant effect present.

In the study of organizational innovation, Zaltman, Duncan, and Holbek (1973) report a strict emphasis on a hierarchy of authority reduces organizational innovativeness. This negative relationship between centralization and organizational innovation is rooted in organization theory. Thompson (1965) states the concentration of decision- making authority prevents innovative solutions. Likewise, Damanpour's (1991) meta-analysis on organizational characteristics reports a negative association between innovation and centralization.

Findings regarding the effect of centralization on innovation success are mixed. Hence, in this study, the author follows the reasoning proposed by Fain and Wagner (2004). As mentioned earlier, Obenchain and Johnson (2004) study both adhocracy and hierarchy cultures in higher education institutions. They find evidence that it is the adhocracy cultures which most favor innovation while hierarchy cultures hinder it. As stated by Cameron and Quinn (1999), hierarchy culture is characterized by stability and internal orientation, which favors decision making by authority, high formalization, an emphasis on internal processes. In the same light, Child (1973) argues that delegation of authority and employee participation in decision making (which means less centralization) fosters learning and development among the members of the organization, which means that they are better equipped to assume the risks of innovation. With that, Fain and Wagner (2014) conclude that when allowing a moderate level of authority, which means less centralization, only then it can be beneficial for new product development success. Given the above, the author hypothesizes:

H2: Moderate level of centralization has a positive effect on product innovation success. 
INTERNATIONAL JOURNAL OF ACADEMIC RESEARCH IN BUSINESS AND SOCIAL SCIENCES Vol. 8, No. 9, Sept. 2018, E-ISSN: 2222-6990 @ 2018 HRMARS

\section{Organizational Climate}

Participatory work environments facilitate innovation by increasing organizational members' awareness, commitment, and involvement (Damanpour, 1991). Obenchain (2002) in her study mentions that the higher education institution administrators should emphasize promoting an organizational culture that is compatible with the operating environment. In relation to the studies on organizational characteristics, most researchers use the work of Burns and Stalker (1961). They note the distinction between innovative and non-innovative organizations along the dimensions of organic versus mechanistic organizational forms (Misyer, Omar, \& Normaziah, 2012).

Giving attention to organizational structure, Bums and Stalker (1961) report that the organizational structure should be related to the environment in which the organization operates. Where the environment is stable and predictable, a mechanistic structure is best. Where the environment is one of change and unpredictability, mechanistic organizations lack the flexibility to cope and an organic structure is required. Since Bums' and Stalkers' (1961) work is published, the view that an organic organizational structure is the most appropriate for facilitating innovation has been widely accepted. Organic organizational structures are flat with temporary workgroups, teams based around specific projects. Lateral communications dominate the organization and job descriptions are flexible. The source of power and authority in organic structures change with changes in circumstances (Burns \& Stalker, 1961; King \& Anderson, 1995).

According to Duxbury (2014), an organizational climate with minimal structures is those that incorporate nominal leadership, personal autonomy, information sharing, and orientation to simple goals (Kamoche \& Cunha, 2001). In line with other findings, Brown and Eisenhardt (1997) note that such "semi-structured", with few explicit rules in achieving goals, favored improvisation. Control systems that reward initiative, effort, and risk-taking without penalizing failed attempts, are as essential to improvisation as they are too creative and innovative activities (Duxbury, 2012). In addition, Obenchain (2002) in her study suggests that certain culture characteristics (such as operating values and processes) are associated with innovation implementation. An awareness of these cultural characteristics might enhance organizational efforts toward innovation implementation.

Fain and Wagner (2014) highlight that an organizational climate is defined as the perception of the organization internal nature by the new product development team members. Factors of organizational climate include role flexibility, joint reward system, values integration, job rotation and interaction with functional leaders (Lu \& Chang, 2002). In their study, results show that both companies in the UK and Slovenia have a good organizational climate that has a direct influence on new product development success.

Gupta, Raj, and Wilemon (1986), in their study of R\&D-marketing interface, use the term "organizational factors" and introduce three dimensions under it: (1) structural; (2) senior management; and (3) R\&D-marketing operating characteristics. Comparing the characteristics of organizational climate (Obenchain, 2002; Duxbury, 2012; Lu \& Chang, 2002; Fain \& Wagner, 2014) to the factors proposed by Gupta, Raj, and Wilemon (1986), this study finds that they are almost similar, particularly, the role of senior management. Senior management can provide an environment that may be either conducive or inhibitive to the development of R\&D. According to Gupta, Raj, and Wilemon (1986), the effects of the role of senior management can be evaluated 
INTERNATIONAL JOURNAL OF ACADEMIC RESEARCH IN BUSINESS AND SOCIAL SCIENCES Vol. 8, No. 9, Sept. 2018, E-ISSN: 2222-6990 @ 2018 HRMARS

based on several criteria: (1) values integration, (2) encourages risk-taking, (3) establishes a joint reward system, and (4) tolerates failures. Given the above, the author hypothesizes:

H3: Organizational climate has a positive effect on product innovation success.

\section{Environmental uncertainty and innovation success}

Changes in demographic patterns and technology have created environmental uncertainty for higher education institutions (Obenchain, 2002). Obenchain (2002) states a high degree of environmental instability and unpredictability can stimulate innovation by making the organization more aware of the need to innovate (Aiken \& Alford, 1970). It is found that environmental complexity has a positive impact on organizational innovation (King \& Anderson, 1995). In contrast, Kimberly (1981) extends the view of environmental turbulence by including organizational structure, stating that, formalization and centralization may facilitate organizational innovation when the environments are relatively stable and predictable, but may impede it by environmental uncertainty. Quinn and Cameron (1999) stress the need for organizational cultures to have compatibility with the demands of their external operating environments.

Dess and Beard (1984) define environmental uncertainty to comprise dynamism, munificence, and complexity dimensions and there are eighteen items used to measure environmental uncertainty based on the stated dimensions (Camisón \& Villar-López, 2014): Dynamism-Frequency of change, instability of demand, the degree of change in market structure, frequency of product innovation, and customer pressure through radical changes in attitude; Munificence-abundance of resources, growth of sales, implicit risk in the activity, and degree of environmental hostility; and Complexity-number of competitors, diversity of consumers, diversity of suppliers, presence of differentiated products, and technological diversity.

In some literature, environmental uncertainty is used as a control variable and in these studies (De Luca \& Atuahene- Gima, 2007; Camisón \& Villar-López, 2014), environmental uncertainty is found to be insignificant when affecting technological innovation capabilities and firm's performance. Similarly, Tatikonda and Montoya-Weiss (2001), in their study, suggest that external uncertainty moderates the relationship between operational outcomes and market outcomes. However, their results do not support their hypotheses.

Wu, Li, and Wang (2014), in their study, mentions that Chinese new ventures face greater environmental uncertainty and resource constraints (Li \& Atuahene-Gima, 2001), which gives them an even stronger desire to search in external knowledge spaces (Zhang \& Li, 2010). They also highlight that China's emerging economy provides many entrepreneurial opportunities and new ventures' growth but at the same time, slows down innovation due to the relative unpredictability of the environment, the poor institutional infrastructure, and under-developed factor markets (Li \& Zhang, 2007).

On the other hand, Gupta, Raj, and Wilemon (1986) study the effects of environmental uncertainty from an organizational information processing requirement perspective and from the need for differentiation and integration of various organizational subsystems perspective. Their study emphasizes the importance of environmental uncertainty to respond to the varying levels of information processing requirements. In that light, Gupta, Raj, and Wilemon (1986) define perceived environmental uncertainty to be the firm's ability to anticipate changes in competitor's strategy, 
INTERNATIONAL JOURNAL OF ACADEMIC RESEARCH IN BUSINESS AND SOCIAL SCIENCES Vol. 8, No. 9, Sept. 2018, E-ISSN: 2222-6990 @ 2018 HRMARS

consumers' new product requirements, technology, the emergence of new competitive forces in the market, and new regulatory constraints on product performance and design. Several studies have concluded that new product development success rests on the combination of technical feasibility and market demand, recognition and interpretation (Gupta, Raj, \& Wilemon, 1986). In this light, environmental uncertainty appears to have a direct negative influence on innovation performance unless it can respond to the varying levels of information processing requirements (Gupta, Raj, \& Wilemon, 1986), depending on the firm's organizational structure (Kimberly, 1981; Quinn \& Cameron, 1999). Hence, given the above, the author hypothesizes:

H4: Environmental uncertainty perceived has a negative effect on product innovation success.

\section{Crowd capability and innovation success}

The use of the crowd as a resource in product innovation projects requires organizations undertaking activities to engage dispersed populations through information systems (IS). Using the knowledgebased view of the organization, Prpić and Shukla (2012) conceptualize a theory of crowd capital to explain. Crowd capital is a heterogeneous knowledge resource generated by an organization, through its use of crowd capability, which is defined by the structure, content, and process by which an organization engages with the dispersed knowledge of individuals-the crowd.

Prpić and Shukla (2012) define crowd capability as "an organizational level capability that is defined by the structure, content, and process of an organization's engagement with the crowd". A crowd is any population of individuals, who supply knowledge to the organization, through crowding capability. A crowd can exist inside of an organization, exist external to the organization or a combination of the two. The "structure" component of crowd capability is the geographical divisions and functional units within an organization and the technological means that they employ to engage a crowd population for the organization. The "structure" component of crowd capability is always an IS-mediated. The "content" of crowd capability constitutes the knowledge, information or data goals that the organization seeks from the population. Meanwhile, the "processes" of crowd capability are defined as the internal procedures that the organization will use to organize, filter, and integrate the incoming knowledge, information, and/or data.

Furthermore, Prpić and Shukla (2012) have defined crowd capability as an organizational level capability and researchers have hypothesized that an organization's capabilities are derived from its resources (Makadok, 2001; Nahapiet \& Ghoshal, 1998). Prpić and Shukla (2012) further argue that the particular structure, content, and processes of the crowd capability employed by an organization will be unique to the organization. Muhdi and Boutellier (2011) find empirical support for motives that lead to participation in firms initiated online innovation communities that are a form of crowdsourcing. Lüttgens et al. (2014) report, based on recent literature, firms need to build dedicated processes and internal capabilities to effectively utilize this opportunity (Bianchi et al., 2011; Dahlander \& Gann, 2010; Foss et al., 2011).

Two important factors that contribute to the process of innovation are an acquisition of resources and stakeholder management (Hall \& Martin, 2005). Unique resources and their combinations are necessary to the achieve advantage over competitors (Barney, 1991). Crowdfunding has these traits, however, their impact on technological product innovations could not be confirmed. In relation to crowdsourcing, on the other hand, the crowd, once diverse, independent and 
INTERNATIONAL JOURNAL OF ACADEMIC RESEARCH IN BUSINESS AND SOCIAL SCIENCES Vol. 8, No. 9, Sept. 2018, E-ISSN: 2222-6990 @ 2018 HRMARS

decentralized, sometimes proves wiser than a single person, which raises the possibilities for innovation (Surowiecki, 2004). The crowd, already engaged as an idea-generator in the process of crowdsourcing, faces an even deeper form of engagement when asked for monetary contributions in crowdfunding (Ordanini et al., 2011). In this light, the author hypothesizes:

H5: Crowd capability has a positive effect on product innovation success.

\section{The mediating role of R\&D-marketing integration}

Cross-functional collaboration refers to the degree of cooperation, the extent of representation, and the contribution of marketing, R\&D, and other functional units in the product innovation process (Fain \& Wagner, 2014; De Luca \& Atuahene-Gima, 2007; Laforet, 2008; Vega-Vázquez, CossíoSilva, \& Martín-Ruíz, 2012). Cross-functional collaboration is intangible and unstructured in that it only reflects the recognition by functional units of their interdependence and their need to cooperate for the benefit of the organization (De Luca \& Atuahene-Gima, 2007). The literature on cross-functional collaboration focuses on R\&D-marketing integration as it gives the most impact on innovation performance. The relationship between marketing and R\&D is considered by Urban, Hauser, and Dholakia (1987), with the conclusion that both R\&D and marketing are critical to the successful development of new products. Effective communication must exist between functions, and management must develop an organization and decision structure that will allow innovation to develop and to create an atmosphere of entrepreneurship. As a result, R\&D- marketing collaboration has long been suggested as a key determinant for the success of product development (Gupta, Raj, \& Wilemon, 1986).

In a study conducted by Jimenez-Zarco, Torrent-Sellens, and Martinez-Ruiz (2012), their results show a direct and significant relationship between market orientation, cooperation, ICT use, and innovation processes in the product area. Yet internal and external cooperation to achieve greater levels of importance, which implies that having information about clients and competitors is the key for organizations. Evanschitzky et al. (2012) state that the results of their meta-analysis study on product innovation success factors show important growth only in cross-functional communication and competitive response intensity.

Past research indicates that various difficulties may occur within the firm to inhibit cross-functional collaboration (Griffin \& Hauser, 1996). The issues, for instance, include differences in work norms, goal settings, and job responsibilities between R\&D and marketing personnel (Griffin \& Hauser, 1996; Maltz \& Kohli, 2000; Tatikonda \& Montoya-Weiss, 2001). For this reason, many researchers have sought to identify factors that may promote R\&D- marketing collaboration (Song \& Thieme, 2006; Fain \& Wagner, 2014; Li \& Chen, 2012). In the past, marketing and management researchers have examined various individuals and organizational factors considered to be related to R\&D-marketing collaboration, including joint reward systems, top management support, crossfunctional training, centralized structure, and job rotation (Kroll \& Liefner, 2008; Lu \& Chang, 2002; Gupta, Raj, \& Wilemon, 1986; Maltz \& Kohli, 2000; Fain \& Wagner, 2014). Interestingly, they focus their studies on formal integrative mechanisms and tend to be organization-initiated (Griffin \& Hauser, 1996), as in the case of this study, but in a different context.

Formalization, centralization, and organizational climate as mentioned earlier are extensively cited as the integrative mechanisms at the R\&D-marketing integration interface, however, findings 
INTERNATIONAL JOURNAL OF ACADEMIC RESEARCH IN BUSINESS AND SOCIAL SCIENCES Vol. 8, No. 9, Sept. 2018, E-ISSN: 2222-6990 @ 2018 HRMARS

regarding their effects are mixed and therefore, cannot be generalized. Parry and Song (1993) for example, discovered that formalization promotes R\&D- marketing integration by reducing role conflicts, but that it may also impede integration by restricting the flow of information between the functions studied. In a study conducted by Fain and Wagner (2014), the best practice model of R\&D-marketing integration does not hold for the studied cases such that the hypotheses derived from the model of R\&D-marketing integration could not be supported. They conclude that the framework might be valid when exploring a large sample of companies at national levels, but need further specifications and expansion when employed in a single case company, in their case, one in the UK and one in Slovenia.

The author finds no relevant empirical studies on the mediating effects of R\&D-marketing integration in the context of higher education institutions. Due to this notion, this study follows the reasoning proposed by Gupta, Raj, and Wilemon (1986) that R\&D-marketing collaboration is the key determinant for the study of product innovation performance.

According to Gupta, Raj, and Wilemon (1986), by conceptualizing the degree of R\&D and marketing involvement and information sharing in the various stages of the innovation process, the managers can better understand their own role and the role of another group. The failure to integrate R\&D and marketing early in the innovation process is one of the biggest contributors to new product failure. R\&D and marketing need to integrate their efforts and the framework proposed could help in identifying specific problem areas. They propose that certain factors related to organizational design and senior management support, along with socio-cultural differences in the orientation of $R \& D$ and marketing managers, will affect the level of integration that can be achieved by an organization (Gupta, Raj, \& Wilemon, 1986). Given the above, the author hypothesizes:

H6: The lower the degree of formalization in higher education institutions, the greater the degree of integration is achieved.

H7: The lower the degree of centralization in higher education institutions, the greater the degree of integration is achieved.

H8: The higher the level of organizational climate practiced in higher education institutions, the greater the degree of integration is achieved.

In addition, Gupta, Raj, and Wilemon (1986) also suggest that a firm's strategy and its perceived environmental uncertainty will influence the extent of R\&D-marketing integration that the firm will ideally require. As mentioned previously, environmental uncertainty comprises uncertainty related to competition, consumer requirements, technological changes, and regulatory constraints. Their model adopts the contingency theory of organizational design to emphasize the importance of environmental uncertainty to respond to the varying levels of information processing requirements. Several studies have concluded that new product development success depends not only on technical feasibility and market demand, but recognition and interpretation of the information are important as well (Gupta, Raj,

\& Wilemon, 1986). 
INTERNATIONAL JOURNAL OF ACADEMIC RESEARCH IN BUSINESS AND SOCIAL SCIENCES Vol. 8, No. 9, Sept. 2018, E-ISSN: 2222-6990 @ 2018 HRMARS

In this light, by embracing cross-functional collaboration, particularly between R\&D and marketing, in terms of (1) marketing-involvement in the R\&D activities, (2) R\&D-involvement in the marketing activities, and (3) marketing- information dissemination, environmental uncertainty can better respond to the varying levels of information processing requirements (Gupta, Raj, \& Wilemon, 1986), depending on the firm's organizational structure (Kimberly, 1981; Quinn \& Cameron, 1999). Given the above, the author hypothesizes:

H9: The higher the environmental uncertainty perceived by higher education institutions, the greater the need for R\&D-marketing integration.

The crowdsourcing market is a highly dynamic field since Howe (2006) uses the term crowdsourcing in his article. One form of crowdsourcing is crowdfunding, which is recently gaining an increasing popularity. Lambert and Schwienbacher (2010) who argue that the use of crowdfunding may be seen as a means to generate a story about a new product or service in order to create or support a marketing campaign in which consumers are able to participate. Crowdfunding allowed both companies to gain market validation and avoid giving up equity or engage in debt before taking a product concept to market. Most importantly with regard to crowdfunding, the online social networks and viral marketing techniques are utilized effectively in order to build the crowd. This finding is important as firms were using their social networks as a means to overcome resource deficiencies supporting the views of Bell et al. (2003), Arenius and De Clercq (2005), and Oviatt and McDougall (2005).

In addition, Byrnes et al. (2014) report on an analysis of the \#SciFund Challenge, a crowdfunding experiment in which 159 scientists attempted to crowdfund their research. The authors suggest that if scientists and research institutions wish to tap this new source of funds, they will need to encourage and reward activities that allow scientists to engage with the public. Their analysis also shows that the engagement of broad audiences is the key to successful science crowdfunding. Crowdfunding participants' roles and activities, in Ordanini et al.'s (2011) suggests that in crowdfunding contexts, consumers are the key players in activating the process and influencing the ultimate value of the offerings or outcomes of the process (Ordanini et al., 2011). Moreover, as Gupta and Govindarajan (2000) stfitren' $\$$ an internal organizational structure determines "the information processing potential between its various sub-units and with the environment". In this light, R\&D and marketing integration should begin at an early stage (during the generation of ideas stage) to gain popularity at the very beginning. This study also suggests R\&D involvement in activities typically performed by marketing may be enhanced and the marketing information gap can be reduced by engaging the crowd. In addition, a few studies have covered the different structural dimensions throughfivunsictopen up their boundaries to identify and utilize knowledge from external sources (Siggelkow \& Levinthal, 2003; Zhang \& Baden- Fuller, 2010). Given the above, the author hypothesizes:

H10: The greater the crowd capability, perceived by higher education institutions, the greater the R\&D- marketing integration.

\section{R\&D-marketing integration and innovation success}

The relationship between marketing and R\&D is considered by Urban, Hauser, and Dholakia (1987), with the conclusion that both $R \& D$ and marketing are critical to the successful development of new products. As a result, since then, many kinds of literature on R\&D-marketing integration 
INTERNATIONAL JOURNAL OF ACADEMIC RESEARCH IN BUSINESS AND SOCIAL SCIENCES

Vol. 8, No. 9, Sept. 2018, E-ISSN: 2222-6990 @ 2018 HRMARS

emerge, particularly in its effects on innovation success (Song \& Thieme, 2006; Jimenez-Zarco, Torrent-Sellens, \& Martinez-Ruiz, 2012; Li \& Chen, 2012; Fain \& Wagner, 2014). Given the above, the author hypothesizes:

H11: The higher the degree of R\&D-marketing integration, the greater the probability of product innovation success.

\section{Theoretical Framework}

In this section, the author explains the underpinning theory behind this study and proposes a conceptual framework to contribute to the literature examining product innovation performance at higher education institutions.

\section{Underpinning Theory}

Gupta, Raj, and Wilemon (1986) theorize the degree of R\&D and marketing involvement and information sharing in the various stages of an innovation process. They suggest that the failure to integrate R\&D and marketing early in the innovation process is one of the biggest contributors to new product failure. Their theory conceptualizes certain factors related to a firm's strategy and its perceived environmental uncertainty, organizational design, and senior management support, along with socio-cultural differences in the orientation of R\&D and marketing managers, will affect the level of integration that can be achieved by an organization (Gupta, Raj, \& Wilemon, 1986). Fain and Wagner (2014), based on the works of Song and Thieme (2006) and Lu and Chang (2002), further specify that the integrative mechanisms (formalization, centralization and organizational climate) influences the cross-functional integration and reducing the gap enhance new product development. Their model assesses the cross-functional integration gap, which is the level of R\&D-marketing integration perceived in companies, by measuring three integration gaps-marketing-involvement gap, R\&D-involvement gap, and marketing-information gap.

In respect to the crowd capital theory, according to Prpić and Shukla (2013), the theory states that dispersed knowledge (crowd) supported by an organizational level capability (crowd capability) can generate an organizational- level heterogeneous resource (crowd capital). Crowd capital is a key resource for an organization that can facilitate the productive and economic activity. On the other hand, crowd capability encompasses IT structure, content, and process of an organization's engagement with a crowd (Prpić \& Shukla, 2013).

Crowd capability, one of the constructs of crowd capital theory, is incorporated in this study. The use of crowd has been linked to open innovation and customer co-creation concept in several kinds of literature (Gustafsson, Kristensson, \& Witell, 2012; Belleflamme, Lambert, \& Schwienbacher, 2014; Belleflamme \& Lambert, 2014; Bretschneider, Knaub, \& Wieck, 2014; Byrnes et al., 2014; Ibrahim \& Verliyantina, 2012; Ingram \& Teigland, 2013; Lambert \& Schwienbacher, 2010; Zheng et al., 2014). Hence, the author suggests that depending on the organizational level 
INTERNATIONAL JOURNAL OF ACADEMIC RESEARCH IN BUSINESS AND SOCIAL SCIENCES Vol. 8, No. 9, Sept. 2018, E-ISSN: 2222-6990 @ 2018 HRMARS

capability with the use of IT, gaining crowd capital is likely to enhance innovation performance at institutions of higher education.

\section{Proposed Framework}

The proposed framework, which the hypotheses are based on, is presented in Figure 1. It is noteworthy that this is the first conceptual framework proposed that incorporates the study of the crowd in the R\&D-marketing integration literature, particularly, in the education sector.

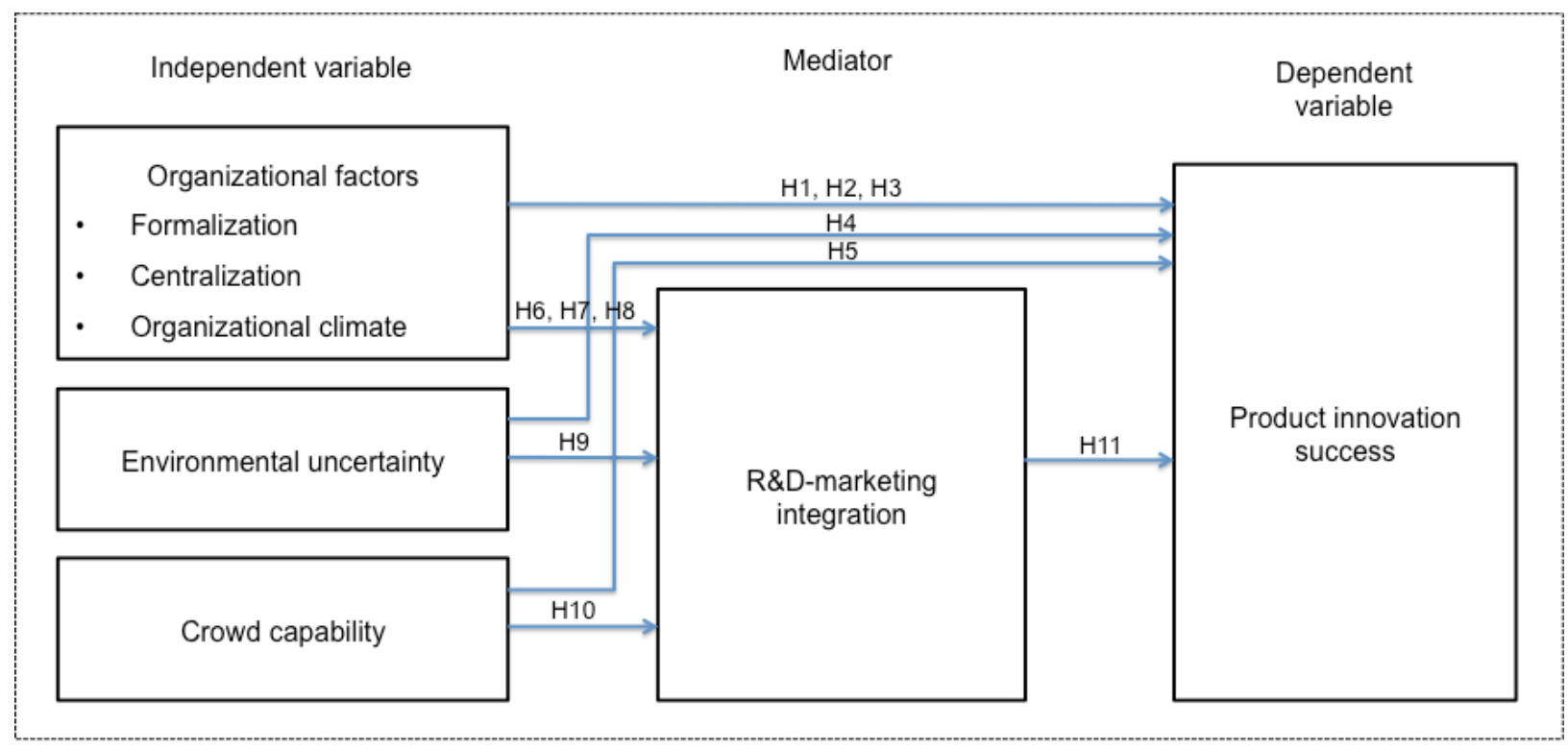

Figure 1: A theoretical framework for the study of the mediating effect of R\&D-marketing integration on NPD success

\section{Implications and Conclusions}

The author expects to make contributions to both theory and practice. The author has introduced a new construct, crowd capability, in the model for the study of R\&D-marketing integration. As it concerns theoretical contributions, it is expected to find empirical evidence for the new construct. By incorporating the crowd and crowd capital theory, R\&D and marketing activities will be ITmediated, and information or knowledge sharing can occur between the project members and the crowd interested in the projects. The framework suggests that depending on the organizational level capability with the use of IT, gaining crowd capital is likely to enhance innovation performance at institutions of higher education, particularly, when R\&D-marketing integration is recognized by the team.

The author is yet to find literature on crowd capability in the Malaysian context, particularly in the education sector. The use of crowd has already been initiated by the non-profit organizations in Malaysia, asking for donations, and by the entertainment industry, requesting the public to vote. The success of a particular project seems to be directly influenced by its campaign, worked out by the team. There may already be small businesses that engage the crowd, but remain unrecorded. Because this study involves the crowd with dispersed knowledge, elements of culture, geographical distance, and human factor could also be incorporated into the study. 
INTERNATIONAL JOURNAL OF ACADEMIC RESEARCH IN BUSINESS AND SOCIAL SCIENCES Vol. 8, No. 9, Sept. 2018, E-ISSN: 2222-6990 @ 2018 HRMARS

As it also concerns practical contributions, the author expects to find evidence for the new construction that sufficiently explains the influence crowd capability, organizational factors, and environmental uncertainty have on R\&D-marketing integration and product innovation performance. The results will be beneficial to the university administrators to systematically design the work process, develop new policy and regulations, and revise organizational structure to facilitate the R\&D and marketing activities, engaging the crowd campaign, and new product commercialization process. The outcome of the study could also determine the degree of formalization, centralization, and organizational climate, which is considered acceptable, allowing the R\&D-marketing information processing requirements to respond to the environmental uncertainty and crowd capital resource to achieve the desired product innovation success.

Byrnes et al. (2014) suggest universities to make crowdfunding as part of a research group and the university's funding portfolio. Making research relevant and accessible is crucial for universities. The amount and significance of new knowledge and technology emerging in research practicing higher education institutions give them a unique role in enhancing development and sustainability.

Many economies globally face the challenge of how making academic research relevant and accessible to society (Etzkowitz, 2008; Wedgwood, 2006; Abd Rahman, Farley, \& Ng, 2013). Turning research results into products and services require higher education institutions to be open and receptive to real-world problems, to enable researchers and students to jointly develop innovative solutions and to be able to disseminate these widely. All these sum up to the "entrepreneurial capacity" of a higher education institution. While learning at the same time and dealing with external stakeholders, it is important to develop this capacity. This implies a move away from the previously narrow focus upon knowledge transfer to a network-based approach to knowledge exchange.

\section{References}

Abd Rahman Ahmad, Farley, A., \& Ng, K. S. (2013). Funding reforms in Malaysian public universities: Transitions towards competitive funding. Australian Journal of Basic and Applied Sciences, 7(10), 553-561.

Aiken, M., \& Alford, R. (1970). Community structure and innovation: The case of urban renewal. American Sociological Review, 35, 650-665.

Alegra, J., \& Chiva, R. (2008). Assessing the impact of organizational learning capability on product innovation performance: An empirical test. Technovation, 28(6), 315-326.

Angle, H. L. (1989). Psychology and organizational innovation. In A. H. Van de Ven, H. L. Angle, \& M. S. Poole (Eds.), Research on the management of innovation: The Minnesota studies (pp. 135170). New York: Harper \& Row.

Antonenko, B. P. D., Lee, B. R., \& Kleinheksel, A. J. (2014). Trends in the crowdfunding of educational technology startups, TechTrends, 58(6), 36-41.

Arenius, P., \& De Clercq, D. (2005). A network-based approach to opportunity recognition. Small Business Economics, 24, 249-265.

Avermaete, T., Viaene, J., Morgan, E. J., \& Crawford, N. (2003). Determinants of innovation in small food firms. European Journal of Innovation Management, 6, 8-17. 
INTERNATIONAL JOURNAL OF ACADEMIC RESEARCH IN BUSINESS AND SOCIAL SCIENCES

Vol. 8, No. 9, Sept. 2018, E-ISSN: 2222-6990 @ 2018 HRMARS

Barber M., Donnelly, K., \& Rizvi, S. (2013). An avalanche is coming. Higher education and the revolution ahead.London: Institute of Public Policy Research.

Barney, J. (1991). Firm resources and sustained competitive advantage. Journal of Management, 17(1), 99-120.

Bell, J., McNaughton, R., Young, S., \& Crick, D. (2003). Towards an integrative model of small firm internationalization. Journal of International Entrepreneurship, 1, 339-362.

Belleflamme, P., \& Lambert, T. (2014). Crowdfunding: Some empirical findings and microeconomic underpinnings. SSRN Electronic Journal, (August), 288-296. doi:10.2139/ssrn.2437786

Belleflamme, P., Lambert, T., \& Schwienbacher, A. (2014). Crowdfunding: Tapping the right crowd. Journal of Business Venturing, 29, 585-609.

Bianchi, M., Cavaliere, A., Chiaroni, D., Frattini, F., \& Chiesa, V. (2011). Organisational modes for open innovation in the biopharmaceutical industry: An exploratory analysis. Technovation, 31, 2233.

Blau, P., \& Scott, W. (1962). Formal organizations: A comparative approach. San Francisco: Chandler publishing.

Bretschneider, U., Knaub, K., \& Wieck, E. (2014, June 9-11). Motivations for crowdfunding: What drives the crowd to invest in start-ups? Paper presented at the 22nd European Conference on Information Systems, Tel Aviv, Israel.

Brown, S. L., \& Eisenhardt, K. M. (1997). The art of continuous change: Linking complexity theory and time-paced evolution in relentlessly shifting organizations. Administrative Science Quarterly, 1-34.

Burg, E., Romme, A. G., Gilsing, V., \& Reymen, I. (2008). Creating university spin-offs: A science-based design perspective. Journal of Product Innovation Management, 25(2), 114-128.

Burns, T., \& Stalker, G. M. (1961). The management of innovation. London: Tavistock.

Byrnes, J. E., Ranganathan, J., Walker, B. L. E., \& Faulkes, Z. (2014). To crowdfund research, scientists must build an audience for their work. PLOS ONE, 9(12), e110329. doi:10.1371/journal.pone.0110329

Calisir, F. (2013). Impacts of learning orientation on product innovation performance. The Learning Organization, 20(3), 176-194.

Cameron, K. (1985). Cultural congruence, strength, and type: Relationships to effectiveness. Paper presented at the meeting of ASHE, Chicago, IL.

Cameron, K. S., \& Quinn, R. E. (1999). Diagnosing and changing organizational culture. Based on the competing values framework. Reading, MA: Addison-Wesley.

Camisón, C., \& Villar-López, A. (2014). Organizational innovation as an enabler of technological innovation capabilities and firm performance. Journal of Business Research, 67, 2891-2902.

Cheng, C. F., Chang, M. L., \& Li, C. S. (2013). Configural paths to successful product innovation. Journal of Business Research, 66, 2561-2573.

Child, J. (1973). Predicting and understanding organizational structure. Administrative Science Quarterly, 18, 168- 185.

Christofi, M., Vrontis, D., \& Leonidou, E. (2014). Product innovation and cause-related marketing success: A conceptual framework and a research agenda. Marketing Intelligence \& Planning, $32,174-189$.

Clark, B. R. (1998). Creating entrepreneurial universities: Organizational pathways of transformation. Oxford: Pergamon Press. 
INTERNATIONAL JOURNAL OF ACADEMIC RESEARCH IN BUSINESS AND SOCIAL SCIENCES

Vol. 8, No. 9, Sept. 2018, E-ISSN: 2222-6990 @ 2018 HRMARS

Clark, B. R. (2001). The entrepreneurial university: New foundations for collegiality, autonomy, and achievement.mJournal of the Programme on Institutional Management in Higher Education (OECD), 13(2), 9-24.

Clark, B. R. (2003). Sustaining change in universities: continuities in case studies and concepts. Tertiary Education and Management, 9, 99-116.

Clark, B. R. (2004). Delineating the character of the entrepreneurial university. Higher Education Policy, 17, 355- 370.

Cooper, L. G. (2000). Strategic marketing planning for radically new products. Journal of Marketing, 64(1), 1-16. Cooper, R. G., \& Kleinschmidt, E. J. (1987). New products: What separates winners from losers. Journal of Product Innovation Management, 4(3), 169-184.

Cormican, K., \& O'Sullivan, D. (2004). Auditing best practice for effective product innovation management.Technovation, 24(10), 819-829.

Dahlander, L., \& Gann, A. M. (2010). How open is open innovation? Research Policy, 39(6), 699-709. Damanpour, F. (1991). Organizational innovation: a meta-analysis of effects of determinants and moderators. Academy of Management Journal, 34(3), 550-90.

Damanpour, F., \& Aravind, D. (2006). Product and process innovations: A review of organizational and environmental determinants. In J. Hage \& M. Meeus (Eds.), Innovation, Science, and Industrial Change: A Research Handbook (pp. 38-66). Oxford: Oxford University Press.

Damanpour, F., \& Gopalakrishnan, S. (2001). The dynamics of the adoption of product and process innovations in organizations. Journal of Management Studies, 38(1), 45-65.

De Luca, L. M., \& Atuahene-Gima, K. (2007). Market knowledge dimensions and cross-functional collaboration: Examining the different routes to product innovation performance. Journal of Marketing, 71(1), 95-112.

Deshpande, R., Farley, J., \& Webster, F. (1993). Corporate culture, customer orientation and innovativeness in Japanese firms: A quadrat analysis. Journal of Marketing, 57, 23-37.

Dess, G. G., \& Beard, D. W. (1984). Dimensions of organizational task environments. Administrative Science Quarterly, 29, 52-73.

Doyle, P. (1994). Setting business objectives and measuring performance. European Management Journal, 12(2), 123-132.

Duxbury, T. (2014). Improvising entrepreneurship improvising entrepreneurship. Technology Innovation Management Review, 4(7), 22-27.

Duxbury, T. (2012). Creativity: Linking theory and practice for entrepreneurs. Technology Innovation Management Review, 2(8), 10-15.

EUA. (2013). Financially sustainable universities. Full costing: Progress and practice. Brussels: European University Association.

Etzkowitz, H. (2008). The triple helix university-industry-government innovation in action. New York: Routledge.

Evanschitzky, H., Eisend, M., Calantone, R. J., \& Jiang, Y. (2012). Success factors of product innovation: An updated meta-analysis. Journal of Product Innovation Management, 29(1994), 21-37.

Fain, N., \& Wagner, B. (2014). R\&D-marketing integration in innovation - does culture matter? European Business Review, 26(2), 169-187.

Forest, J., \& Altbach, P. (2006). International handbook of higher education. Springer Verlag.

Foss, N. J., Laursen, K., \& Pedersen, T. (2011). Linking customer interaction and innovation: The mediating role of new organizational practices. Organization Science, 22(4), 980-999. 
INTERNATIONAL JOURNAL OF ACADEMIC RESEARCH IN BUSINESS AND SOCIAL SCIENCES

Vol. 8, No. 9, Sept. 2018, E-ISSN: 2222-6990 @ 2018 HRMARS

Ganter, A., \& Hecker, A. (2014). Configurational paths to organizational innovation: Qualitative comparative analyses of antecedents and contingencies. Journal of Business Research, 67(6), 1285-1292.

Ganter, A., \& Hecker, A. (2013). Deciphering antecedents of organizational innovation. Journal of Business Research, 66(5), 575-584.

Garett, T. C., Buisson, D. H., \& Yap, C. M. (2006). National culture and R\&D and marketing integration mechanisms in new product development: A cross-cultural study between Singapore and New Zealand. Industrial Marketing Management, 35, 293-307.

Gemunden, H. G., \& Heydebreck, P. (1992). Technological interweavement: A means of achieving innovation success. R\&D Management, 22(4), 359-376.

Gibb, A. A. (2013). Developing the entrepreneurial university of the future. Key challenges, opportunities, and responses. Paris: OECD.

Greene, P. G., \& Brown, T. E. (1997). Resource needs and the dynamic capitalism typology. Journal of Business Venturing, 12, 161-173.

Griffin, A., \& Hauser, J. R. (1996). Integrating R\&D and marketing: A review and analysis of the literature. Journal of Product Innovation Management, 13, 191-215.

Gupta, A. K., \& Govindarajan, V. (2000). Knowledge flows within multinational corporations. Strategic Management Journal, 21(4), 473-496.

Gupta, A. K., Raj, S. P., \& Wilemon, D. (1986). A model for studying R\&D--marketing interface in the product innovation process. Journal of Marketing, 50, 7-17.

Gustafsson, A., Kristensson, P., \& Witell, L. (2012). Customer co-creation in service innovation: A matter of communication? Journal of Service Management, 23(3), 311-327.

Hall, J. K., \& Martin, M. J. C. (2005). Disruptive technologies, stakeholders and the innovation valueadded chain: A framework for evaluating radical technology development. $R \& D$ Management, 35(3), 273-283.

Handscombe, R. D. (2003). The promotion of an entrepreneurial culture in universities-capturing the change in the cultural web. Industry and Higher Education, 17(3), 219-222.

Hise, R. T., \& O'Neal, L. (1990). Marketing/R\&D interaction in new product development implications for new product success rates. Journal of Product Innovation Management, 7(2), 142-155.

Hisrich, R. D., \& Peter, M. P. (1992). Entrepreneurship: Starting, developing, and managing a new enterprise (2nd ed.). Homewood, IL: Irwin.

Hollenstein, H. (1996). A composite indicator of a firm's innovativeness: An analytical analysis based on survey data for Swiss manufacturing. Research Policy, 25, 633-645.

Howe, J. (2006). The Rise of Crowdsourcing. Wired Magazine, 14(6).

Huang, X., Soutar, G. N., \& Brown, A. (2004). Measuring new product success: An empirical investigation of Australian SMEs. Industrial Marketing Management, 33, 117-123.

Hurley, R., \& Hult, T. (1998). Innovation, market orientation, and organizational learning: An integration and empirical examination. Journal of Marketing, 62(July), 42-54.

Ibrahim, N., \& Verliyantina (2012). The model of crowdfunding to support small and micro businesses in Indonesia through a web-based platform. Procedia Economics and Finance, 4(2012), 390397.

Im, S., Montoya, M. M., \& Workman, J. P. (2013). Antecedents and consequences of creativity in product innovation teams. Journal of Product Innovation Management, 30(1), 170-185. 
INTERNATIONAL JOURNAL OF ACADEMIC RESEARCH IN BUSINESS AND SOCIAL SCIENCES

Vol. 8, No. 9, Sept. 2018, E-ISSN: 2222-6990 @ 2018 HRMARS

Ingram, C., \& Teigland, R. (2013). Crowdfunding among IT entrepreneurs in Sweden: A qualitative study of the funding ecosystem and ICT entrepreneurs' adoption of crowdfunding. SSRN Electronic Journal, (June), 1-49.

Jimenez-Zarco, A. I., Torrent-Sellens, J., \& Martinez-Ruiz, M. P. (2012). Proactive orientation effects on product innovation activities: Empirical evidence. Innovation: Management, Policy and Practice, 14(1), 90-106.

Kamoche, K., \& Cunha, M. P. (2001). Minimal structures: From jazz improvisation to product innovation. Organization Studies, 22(5), 733-764.

Kapelko, M. (2006). Evaluating efficiency in the framework of the resource-based view of the firm: Evidence from Polish and Spanish textile and clothing industry. Bellaterra, 1, 1-56.

Kasim, N. A. A., Minai, B., \& Chun, L. S. (1989). Performance measures in Malaysia - The state of the art. Malaysian Management Review, 24, 3-9.

Katila, R., \& Ahuja, G. (2002). Something old, something new: A longitudinal study of search behavior and new product introduction. Academic Management Journal, 45, 1183-1194.

Kimberly, J. (1981). Managerial innovation. In W. Starbuck \& P. Nystrom (Eds.), Handbook of Organizational Design (pp. 84-104). New York: Oxford University Press.

King, N. (1990). Innovation at work: The research literature. In M. West \& J. Farr (Eds.), Innovation and creativity at work (pp. 15-61). New York: John Wiley and Sons.

King, N., \& Anderson, N. (1995). Antecedents to organizational innovation. In C. Fletcher (Ed.), Innovation and Change in Organizations (pp. 95-114). New York: Routledge.

Klofsten, M. (2013). Entrepreneurial universities - An analytical framework and rationale for policy support. Paris: OECD.

Kohler, J., \& Huber, J. (Eds.). (2006). Higher education governance between democratic culture, academic aspirations and market forces. Strasbourg: Council of Europe Publishing.

Kothari, S., \& Handscombe, R. D. (2007). Sweep or seep? Structure, culture, enterprise, and universities. Management Decision, 45(1), 43-61.

Kroll, H., \& Liefner, I. (2008). Spin-off enterprises as a means of technology commercialization in a transforming economy-evidence from three universities in China. Technovation, 28(5), 298313.

Kuppuswamy, V., \& Bayus, B. L. (2014). Crowdfunding creative ideas: The dynamics of project backers in Kickstarter. UNC Kenan-Flagler Research Paper, (2013-2015).

Laforet, S. (2008). Size, strategic, and market orientation effects on innovation. Journal of Business Research, 61, 753-764.

Lambert, T., \& Schwienbacher, A. (2010). An empirical analysis of crowdfunding. SSRN Electronic Journal, 1-23. Retrieved from http://www.crowdsourcing.org/document/an-empirical-analysisof-crowdfunding-/2458

Lüttgens, D., Pollok, P., Antons, D., \& Piller, F. (2014). Wisdom of the crowd and capabilities of a few: Internal success factors of crowdsourcing for innovation. Journal of Business Economics, 84, 339-374.

Lee, C. Y., Wu, H. L., \& Pao, H. W. (2014). How does R\&D intensity influence firm explorativeness? Evidence of R\&D active firms in four advanced countries. Technovation, 34, 582-593.

Li, P. C., \& Chen, Y. C. (2012). How does social orientation influence R\&D-marketing collaboration? Asia Pacific Journal of Management, 29, 151-168.

Li, H. Y., \& Atuahene-Gima, K. (2001). Product innovation strategy and the performance of new technology ventures in China. Academy of Management Journal, 44(6), 1123-1134. 
INTERNATIONAL JOURNAL OF ACADEMIC RESEARCH IN BUSINESS AND SOCIAL SCIENCES

Vol. 8, No. 9, Sept. 2018, E-ISSN: 2222-6990 @ 2018 HRMARS

Li, H. Y., \& Zhang, Y. (2007). The role of managers' political networking and functional experience in new venture performance: Evidence from China's transition economy. Strategic Management Journal, 28(8), 791-804.

Lily Julienti Abu Bakar, \& Hartini Ahmad. (2010). Assessing the relationship between firm resources and product innovation performance: A resource-based view. Business Process Management Journal, 16(3), 420-435.

Löfsten, H. (2014). Product innovation processes and the trade-off between product innovation performance and business performance. European Journal of Innovation Management, 17(1), 61-84.

Lu, I., \& Chang, T. (2002). A contingency model for studying R\&D-marketing integration in NPD. International Journal of Technology Management, 24(2/3), 143-164.

Lukas, B., \& Ferrell, O. C. (2000). The effect of market orientation on product innovation. Journal of the Academy of Marketing Science, 28(2), 239-247.

Makadok, R. (2001). Toward a synthesis of the resource-based view and dynamic-capability: Views of rent creation.Strategic Management Journal, 22(5), 387-401.

Maltz, E., \& Kohli, A. K. (2000). Reducing marketing's conflict with other functions: The differential effects of integrating mechanisms. Journal of the Academy of Marketing Science, 28, 479492.

Mei-Chih Hu, \& Mathews, J. A. (2009). Estimating the innovation effects of university-industrygovernment linkages: The case of Taiwan. Journal of Management \& Organization, 15(2), 138-154.

Miller, D. (1992). Handbook of Research Design and Social Measurement. California: Sage Publications, Inc.

Misyer Mohamed Tajudin, Omar Musa, \& Normaziah Che Musa. (2012). Effects of organizational culture, market orientation, and innovativeness toward new product performance amongst Malaysian SMEs. International Journal of Innovation and Business Strategy, 01, 24-48.

Muhdi, L., \& Boutellier, R. (2011). Motivational factors affecting participation and collaboration of members in two different Swiss Innovation communities. International Journal of Innovation Management, 15(3), 543-562.

Nahapiet, J., \& Ghoshal, S. (1998). Social capital, intellectual capital, and the organizational advantage. Academy of Management Review, 23(2), 242-266.

Neal, R., \& Radnor, M. (1971, October). The relationship between formal procedures for pursuing OR/MS activities and OR/MS group success. Paper presented at the 40th National Conference of the Operations Research Society of America, Anaheim, California.

Nee, V., Kang, J., \& Opper, S. (2010). A Theory of Innovation: Market Transition, Property Rights, and Innovative Activity. Journal of Institutional and Theoretical Economics JITE, 166(August), 397425.

Niammuad, D., Napompech, K., \& Suwanmaneepong, S. (2014). Entrepreneurial product innovation: A second-order factor analysis. The Journal of Applied Business Research - January/February 2014, 30(1), 197-210.

Obenchain, M. (2002). Organizational culture and organizational innovation in not-for-profit, private and public institutions of higher education. Unpublished doctoral dissertation, Nova Southeastern University, Davie, FL. 
INTERNATIONAL JOURNAL OF ACADEMIC RESEARCH IN BUSINESS AND SOCIAL SCIENCES Vol. 8, No. 9, Sept. 2018, E-ISSN: 2222-6990 @ 2018 HRMARS

Obenchain, A. M., \& Johnson, W. C. (2004). Product and process innovation in service organizations: The influence of organizational culture in higher education institutions. Journal of Applied Management and Entrepreneurship, 9(3), 91-113.

O'Cass, A., \& Sok, P. (2014). The role of intellectual resources, product innovation capability, reputational resources, and marketing capability combinations in SME growth. International Small Business Journal, 32(8), 996- 1018.

Olavarrieta, S., \& Friedmann, R. (2008). Market orientation, knowledge-related resources, and firm performance. Journal of Business Research, 61, 623-630.

Ordanini, A., Miceli, L., Pizzetti, M., \& Parasuraman, A. (2011). Crowd-funding: Transforming customers into investors through innovative service platforms. Journal of Service Management, 22(4), 443-470.

Otero-Neira, C., Arias, M. J. F., \& Lindman, M. T. (2013). Market orientation and entrepreneurial proclivity: Antecedents of innovation. Global Business Review, 14(3), 385-395.

Oviatt, B. M., \& McDougall, P. P. (2005). Defining international entrepreneurship and modeling the speed of internationalization. Entrepreneurship Theory and Practice, 29, 537-554.

Perkman, M. et al. (2013). Academic engagement and commercialization: A review of the literature. Research Policy, 43, 423-442.

Phelps, C. C. (2010). A longitudinal study of the influence of alliance network structure and composition on firm exploratory innovation. Academic Management Journal, 53, 890-913.

Pierce, J., \& Delbecq, A. (1977). Organizational structure, individual attitude, and innovation. Academy of Management Review, 2, 27-33.

Prpić, J., \& Shukla, P. (2012, September). The theory of crowd capital. In Proceedings of the Annual Hawaii International Conference on System Sciences, (September 2012), 3505-3514.

Prpic, J., Shukla, P., Roth, Y., \& Lemoine, J. (2015). A geography of participation in IT-mediated crowds. In Proceedings of the 48th Hawaii International Conference on Systems Sciences. Kauai, Hawaii, USA: IEEE Computer Society Press.

Raja Suzana Raja Kasim. (2011). Malaysian higher education institutions: Shaping an entrepreneurial agenda. Internal Journal of Information and Education Technology, 1(2), 163-170.

Rogers, E. (1983). Diffusion of Innovations. New York: The Free Press.

Rogers, E. (1995). Diffusion of Innovations (4th ed.). NewYork: The Free Press.

Shattock, M. (2003). Managing successful universities. Buckingham: SRHE/Open University Press.

Shattock, M. (2010). The entrepreneurial university: An idea for its time. London Review of Education, $8(8), 263-271$.

Shinn, J. (1996). The effects of executive leadership on organizational innovation in nonprofit, human service organizations. Unpublished doctoral dissertation, University of Pittsburgh, Pittsburgh.

Silva, G. M., Gomes, P. J., Lages, L. F., \& Pereira, Z. L. (2014). The role of TQM in strategic product innovation: An empirical assessment. International Journal of Operations \& Production Management, 34(10), 1307-1337.

Siggelkow, N., \& Levinthal, D. A. (2003). Temporarily divide to conquer: Centralized, decentralized, and reintegrated organizational approaches to exploration and adaptation. Organization Science, 14(6), 650-669.

Smart, J., \& St. John, E. (1996). Organizational culture and effectiveness in higher education: A test of the "culture type" and "strong culture" hypotheses. Educational Evaluation and Policy Analysis, 18(3), 219-241. 
INTERNATIONAL JOURNAL OF ACADEMIC RESEARCH IN BUSINESS AND SOCIAL SCIENCES Vol. 8, No. 9, Sept. 2018, E-ISSN: 2222-6990 @ 2018 HRMARS

Smilor, R. W. (1987). Managing the incubator system: Critical success factors to accelerate new company development. IEEE Transactions on Engineering Management, EM-34(3), 146-155.

Song, M., \& Thieme, R. J. (2006). A cross-national investigation of the R\&D-marketing interface in the product innovation process. Industrial Marketing Management, 35, 308-322.

Sporn, B. (1999). Adaptive university structures. An analysis of adaptations to socioeconomic environments of US and European universities. London: Jessica Kingsley.

Surowiecki, J. (2004). The wisdom of crowds. Why the many are smarter than the few (5th ed.). London: Abacus.

Tatikonda, M. V., \& Montoya-Weiss, M. M. (2001). Integrating operations and marketing perspectives of product innovation: The influence of organizational process factors and capabilities on development performance. Management Science, 47(1), 151-172.

Thompson, V. (1965). Bureaucracy and innovation. Administrative Science Quarterly, 5, 1-20.

Urban, G. L., Hauser, J. R., \& Dholakia, N. (1987). Essentials of new product management. Englewood Cliffs, NJ: Prentice-Hall.

UTHM., 2009. IPTA dibenar belanja dana peroleh sendiri. Retrieved 12 April 2015 http://www.uthm.edu.my/v2/content/view/480/229/lang,en/

Valencia, J. C. N., Valle, R. S., \& Jiménez, D. J. (2010). Organizational culture as determinant of product innovation. European Journal of Innovation Management, 13(4), 466-480.

Vega-Vázquez, M., Cossío-Silva, F. J., \& Martín-Ruíz, D. (2012). Does the firm's market orientation behaviour influence innovation's success? Management Decision, 50(8), 1445-1464.

Von der Heidt, T. (2008). Developing and testing model of cooperative interorganizational relationships (IORS) in product innovation in an Australian manufacturing context: A multistakeholder perspective. Unpublished doctoral dissertation, Southern Cross University, Lismore, Australia.

Wedgwood, M. (2006). Mainstreaming the third stream. In I. McNay (Ed.), Beyond mass higher education: Building on experience. Maidenhead, UK: SRHE/Open University Press.

Wetering, A., \& Koster, S. (2007). Inheriting knowledge and sustaining relationships: What stimulates the innovative performance of small software firms in the Netherlands? Research Policy, 36, 320-335.

Williams, G. (2009). Finance and entrepreneurial activity in higher education in a knowledge society. In M. Shattock (Ed.), Entrepreneurialism in universities and the knowledge economy: Diversification and organizational change in European Higher Education, 8-32.

Wu, A., Li, S., \& Wang, H. (2014). New ventures, product innovation, and business intermediaries. Chinese Management Studies, 8(2), 241-257.

Yahya, M., \& Abdullah, I. H. (2004). Challenges of corporatization and globalization: Educational reform in tertiary education. Paper presented at the 27th HERDSA Annual Conference, Miri, Sarawak.

Zairi, M. (1995). Moving from continuous to discontinuous innovation in FMCG: A re-engineering perspective. World Class Design to Manufacture, 2(5), 32-7.

Zaltman, G., Duncan, R., \& Holbek. (1973). Innovations and organizations. New York: Wiley and Sons. Zammuto, R., \& Krakower, J. (1991). Quantitative and qualitative studies of organizational culture. In R. W.

Woodman \& W. A. Pasmore (Eds.), Research in organizational change and development (pp. 59-82). London: JAI Press. 
INTERNATIONAL JOURNAL OF ACADEMIC RESEARCH IN BUSINESS AND SOCIAL SCIENCES Vol. 8, No. 9, Sept. 2018, E-ISSN: 2222-6990 @ 2018 HRMARS

Zhang, J., \& Baden-Fuller, C. (2010). The influence of technological knowledge base and organizational structure on technology collaboration. Journal of Management Studies, 47(4), 679-704.

Zhang, Y., \& Li, H. Y. (2010). Innovation search of new ventures in a technology cluster: The role of ties with service intermediaries. Strategic Management Journal, 31(1), 88-109.

Zheng, H., Li, D., Wu, J., \& Xu, Y. (2014). The role of multidimensional social capital in crowdfunding: A comparative study in China and the US. Information \& Management, 51(4), 488-496. 